\title{
Re-Examination of Biological Traces in Sexual Assault Case by a Fragmental DNA Profiling: a Practical Approach
}

\section{Apostolov $\mathrm{A}^{1 *}$, Hristov $\mathrm{S}^{1}$, Angelova $\mathrm{E}^{1}$, Krastev $\mathrm{D}^{2}$, Kalniev $\mathrm{M}^{3}$ and Krastev $\mathrm{N}^{3}$}

${ }^{1}$ Medical University - Sofia, Faculty of Medicine, Department of Forensic Medicine and Deontology, Bulgaria

${ }^{2}$ Medical University - Sofia, Bulgaria

${ }^{3}$ Department of Anatomy and Histology Medical University, Sofia, Bulgaria

\section{Introduction}

The identification and proof of performed intercourse using DNA analysis of biological traces in cases of rape during forensic tests is a difficult but not unsolvable expert task $[1,2]$.

Generally the used technical methods for collection of DNA traces by wiping with cotton or nylon swabs as well as cutting out small sections of material carriers of biological traces, are common [3]. Cotton swabs for taking vaginal and / or anal smears are routinely used in practice for examinations of women, who were the subject of a sexual crime [4]. It is an undisputed fact that not detecting sperm in the vaginal or anal content of the raped person does not exclude the possibility of them having had a sexual intercourse [5] or a penetration of the penis without ejaculation. With such preliminary information, the studies of evidence gathered during the investigation are directed to a search for biological material of epithelial cells [6].

Studies on this broad scale topic have shown successful analysis of the samples taken in an interval of 48 hours to 8 days after the sexual crime, as the sperm can be found in the investigation of material from oral and anal swabs in this time interval [5,7].

In case of sex crimes, the collection of sufficient and suitable material for DNA analysis is complicated due to material's deposition on highly destructive environment, especially when the sperm is deposited into the rectum where it is destroyed by bacterial enzymes or in the oral cavity where it is destroyed by salivary enzymes [8].

In this study, we focused our attention on the possibilities for extraction of genetic profiles on $\mathrm{Y}$ chromosomal genetic markers of the sex offenders, despite the destructive effect of anal content and minimal biological material left on already tested evidence. It is exactly the collection of a maximum quantity of DNA with good quality preserved after initially unsuccessfully examined vaginal and anal swabs, which is a serious scientific and practical challenge.

\section{Material and Methods}

We present the case of a raped 65- year- old woman with subsequent killing and dismemberment of the victim. The initial studies of vaginal and anal / rectal smears conducted by serological methods were unsuccessful and could not led to the identification of the perpetrators of sexual crimes, respectively murder.

Smears from 3 vaginal and 2 anal swabs, taken during the inspection and the autopsy, and organic material from three men, suspected of committing the crime have been examined by DNA fragmental analysis. For DNA extraction from anal and vaginal swabs, we used a modified technique for collecting biological material, consistent with the presumptive deposition of organic materials (epithelial cells) on wood and plastic handles of cotton swabs, which had already been investigated. Considering the fact that a substantial part of cotton swabs was 'lost' in the previous studies by serological methods, we tried to find alternative sites for deposition of biological material and to apply different approaches for collecting of sufficient and suitable material for DNA analysis. In this case, we complied with the results of our previous experimental and expert research.

We set ourselves the goal to determine the possibility for proof of sexual contact by finding cellular material deposited on examined carriers - wood and plastic handles of the cotton swabs.

After an initial analysis and assessment of the risk, we chose the approach for direct extraction of DNA from post coital samples and refrained from the use of techniques for applying differential lysis, in which we could lose valuable quality and quantity of stored DNA. For the same reason we decided to use a comparative analysis based on $\mathrm{Y}$ chromosome profiling.

We applied the approach of collection of biological material from smears with swabs with wooden and plastic handles using double tampon technique as in Sweet [9] with a further scraping of material from the surface of the wooden handles, in their middle third.

We applied the legal record of the FBI, provided by LIFE TECHNOLOGIES (Debra Nickson, technical services; 29.01.97) for extraction and eventual extraction of DNA from a sample set of material evidence. We used Stain Extraction Buffer with features 0.01 M Tris, 0.01 EDTA, $0.1 \mathrm{M} \mathrm{NaCl}, 0.039 \mathrm{M}$ DTT, $2 \%$ SDS, with which we poured the smears on the handles - carriers and the scraped fragments from the handles, and we added Proteinase $\mathrm{K}(25 \mathrm{mg} / \mathrm{ml})$ in addition. After incubation for 18 hours at $56^{\circ} \mathrm{C}$, an organic phenol extraction (phenol: chloroform: isoamyl alcohol=25:24:1) was performed. DNA precipitation was carried out by absolute alcohol cooled to $-20^{\circ} \mathrm{C}$. Extracted DNA was dissolved in $50 \mu \mathrm{l} \mathrm{TE}-4$ Buffer at the next storage at $-20^{\circ} \mathrm{C}$. The extraction of DNA from the buccal mucosa smears of the examined individuals was conducted in accordance with the provisions of Promega Corporation [10].

The DNA quantity in the sample obtained from the swab handles ranged from $90 \mathrm{pg}-150 \mathrm{pg}$ genomic DNA. DNA quantitation was performed using slot-blot procedure according to the Waye et al. [11].

${ }^{*}$ Corresponding author: Aleksandar Apostolov, Medical University of SofiaFaculty of Medicine, Department of Forensic Medicine and Deontology, DNA laboratory, 1431 Sofia, Bulgaria, 2, Zdrave" str., Fax: 0359029230 412; E-mail: alexa2000@mail.bg

Received July 02, 2013; Accepted July 15, 2013; Published July 19, 2013

Citation: Apostolov A, Hristov S, Angelova E, Krastev D, Kalniev M, et al. (2013) Re-Examination of Biological Traces in Sexual Assault Case by a Fragmental DNA Profiling: a Practical Approach. J Forensic Res 4: 184. doi:10.4172/21577145.1000184

Copyright: (c) 2013 Apostolov A, et al. This is an open-access article distributed under the terms of the Creative Commons Attribution License, which permits unrestricted use, distribution, and reproduction in any medium, provided the original author and source are credited. 


\section{Amplification and Typing}

The polymerase chain reaction (PCR) was conducted on Peltier Termal Cycler 200 (MJ Research USA) with di-, tri- and quadriplex PCR amplifications in 12,5 $\mu$ l volume containing 4-5 $\mu$ l of template for samples from the stems of swab handles and $1 \mu$ for each of the other samples. That volume also included: $1 \mathrm{X}$ Buffer, $1.5 \mathrm{mM} \mathrm{MgCl}, 0.2 \mathrm{mM}$ dNTPs, $0.17 \mathrm{mg} / \mathrm{ml} \mathrm{BSA}$, Cy 5 'Primer A and Primer B (Amersham Pharmacia Biotech) $0.4 \mathrm{pmol} / \mu \mathrm{l}$ of Y-chromosomal STR's markers for samples of evidence, 1U-Platinium Taq DNA polymerase (GibcoBRL) and for the reference material samples (from examined persons) $1 \mathrm{U}$ Taq DNA polymerase (Amersham Pharmacia Biotech), $\mathrm{ddH}_{2} \mathrm{O}$.

For locus DYS438, amplification was completed using initial denaturation $1 \mathrm{cycle}$ at $94^{\circ} \mathrm{C}$ for $3 \mathrm{~min}, 30$ cycles of denaturation at $94^{\circ} \mathrm{C}$ for $30 \mathrm{~s}$, annealing at $56^{\circ} \mathrm{C}$ for $30 \mathrm{~s}$, extension at $72^{\circ} \mathrm{C}$ for $35 \mathrm{~s}, 1 \mathrm{cycle}$ final extension at $72^{\circ} \mathrm{C}$ for $3 \mathrm{~min}$ and $4^{\circ} \mathrm{C}$ hold. STR loci DYS439, DYS19, DYS447 and DYS385 a/b quadriplex amplification characteristics included 1 cycle at $94^{\circ} \mathrm{C}$ for $5 \mathrm{~min}, 30$ cycles of denaturation at $94^{\circ} \mathrm{C}$ for 30 s, annealing at $53^{\circ} \mathrm{C}$ for $45 \mathrm{~s}$, extension at $72^{\circ} \mathrm{C}$ for 40 s, 1 cycle at $72^{\circ} \mathrm{C}$ for $5 \mathrm{~min}$ and $4^{\circ} \mathrm{C}$ hold. For the rest STR loci we used amplification conditions parameters for uni- and multiplex PCR as described by Zaharova et al. [12].

Fragmental analysis was performed using automatic sequencer ALFexpress" DNA Sequencer (Amersham Pharmacia Biotech) by ultrathin $(0.5 \mathrm{~mm}$ thickness of the gel on the short thermocassette) vertical, denaturing polyacrylamide high voltage electrophoresis with

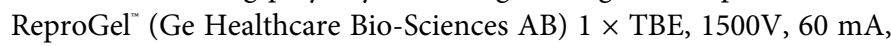
$25 \mathrm{~W}, 50^{\circ} \mathrm{C}$, laser detection of fragments and computer analysis by Fragment manager ${ }^{\mathrm{TM}}$ V1.2 Software (Amersham Pharmacia Biotech) $[13,14]$.

Analysis control was accomplished by: internal standards - AMEL 106 BP and H16401- L16110 347 BP, external standard Sizer 50- 500 (Amersham Pharmacia Biotech) and sequenced allelic ladders for relevant STR markers, as it is at Decorte [12].

\section{Results}

After the initial discussions we set samples from the handles from anal and rectal swabs, smeared using the double swab technique, together with additional surface scrapings from the middle third of the wooden handles.

The results obtained by electrophoretic analysis and laser detection for PCR products of the tested material from the swab handles and from scrapings of wood material in the middle third demonstrated that the same full genetic profile of $10 \mathrm{Y}$ chromosome markers was produced from one of the examined vaginal swab and from one of the anal swabs. The rest tested two vaginal and one anal swab gave a negative result and DNA from a man was not identified. The results are shown in Tables 1 and 2.

Two of the analyzed samples (one vaginal and one anal swab) helped to differentiate a complete Y-chromosome profile, identical to the profile of one of the three males, subjected to a comparative study (Male 3).

The test results illustrate the presence of preserved human cellular material, deposited on the handles of the examined swabs, which was not retrieved in the initial studies carried out.

\section{Discussion}

The technique applied by us for the collection of biological material from the wooden handles smeared and scraped sections of their middle third, led to the differentiation of a complete Y-chromosome profile on the applied $10 \mathrm{Y}$ chromosome markers, identical to the genetic profile of one of the three male suspects. This result can be explained by the presence of pores on the timber carrier, and the deposition of cellular material within the pores of the sampled wood material. Biological material, consisting mainly of epithelial cells, which we were in search of, had been preserved namely in the pores of the wood swab handles. These pores act as a collector and kept the material away from adverse external and bacterial impact. Meanwhile, the dry timber aided the rapid drying and storage of biological materials, yielding the aqueous phase from the organic mixture. Thus the destructive effect of the bacterial colonies and especially of the bacterial enzymes, developing in the vaginal and anal / rectal secretions, was limited. This effect is limited in smearing smooth surfaces, such as those of the swab handles, made of plastic.

The choice of the direct organic phenol: chloroform: isoamylalcohol /25:24:1/ technique for DNA extraction showed very good results, having in mind the very small quantity of DNA of the cell material, which had been deposited on the swab handles.

DNA profiling on autosomal genetic markers proved to be difficult due to the impossibility to differentiate the mixed male and female genetic profiles. This ensured the DNA profiling on particular STRs markers, taking into account the different conditions of collection and examination of the biological material. The applied approach led to overcome of the effects of the DNA loss during the unsuccessful initial serological tests, which reduced the examined cotton swabs as carriers of a biological material.

The right presumptive localization and selection of the technique for isolating the biological material from the evidence are important factors for success and achieving optimal results in DNA profiling. The collection of carrier objects, on which it is possible to transmit and

marker, bp

\begin{tabular}{|c|c|c|c|c|}
\hline & DYS393 & DYS19 & DYS390 & DYS392 \\
\hline $\begin{array}{c}\text { Vaginal smear from the crime site } \\
\text { - serology 2 }\end{array}$ & 124 & 186 & 215 & 245 \\
\hline $\begin{array}{c}\text { Anal smear from an autopsy - } \\
\text { serology 5 }\end{array}$ & 124 & 186 & 215 & 245 \\
\hline Male 1 & 124 & 190 & 207 & 245 \\
\hline Male 2 & 120 & 194 & 207 & 245 \\
\hline Male 3 & 124 & 186 & 215 & 245 \\
\hline
\end{tabular}

Table 1: Distribution of alleles in four $Y$ chromosome STR markers in the corresponding examined loci, forming DNA profiles of the compared samples and individuals.

marker, bp

\begin{tabular}{|c|c|c|c|r|c|}
\hline & DYS447 & DYS439 & DYS438 & DYS389 & DYS385 a/b \\
\hline $\begin{array}{c}\text { Vaginal smear from the } \\
\text { crime site - serology 2 }\end{array}$ & 222 & 128 & 153 & 247 & $273 / 277$ \\
\hline $\begin{array}{c}\text { Anal smear from an } \\
\text { autopsy- serology 5 }\end{array}$ & 222 & 128 & 153 & 247 & $273 / 277$ \\
\hline Male 1 & 202 & 128 & 153 & 243 & $257 / 257$ \\
\hline Male 2 & 212 & 124 & 148 & 251 & $261 / 269$ \\
\hline Male 3 & 222 & 128 & 153 & 247 & $273 / 277$ \\
\hline
\end{tabular}

Table 2: Distribution of alleles on six $Y$ chromosome STR markers in the corresponding examined loci, forming DNA profiles of the compared samples and individuals. 
deposit material from the seminal fluid and/ or epithelial cell material, is important, but an important detail in their examination is the type and structure of the trace-carrying surface.

Achieving this goal goes through careful assessment and localization of the possible sites for deposition of genetic material in the course of vaginal and anal / rectal smears. The results of this study showed that the material of the swabs handles and more precisely the presence of the micro pores and fissures in the wooden handle of the swab plays an important role in the success of the studies. Thus, it may be suggested that for this type of investigation the wood handles are better material, which could be considered as precondition for extended studies.

According to us the specific in these cases is that the handle of the swab may be used to collect biological material, deposited in the area of the anal sphincter. This would be important as it is in this anatomic region it may be expected that in some cases the destructive microorganisms in fecal matter would be more limited in contrast to the materials collected inside of the rectum, where the destructive effect is expected and is undeniable. In practice this discussion would help to increase the rate of successful DNA profiling of perpetrators of sexual crimes, which is supported by the results of our research. At the same time, the results of the study show an alternative for DNA extraction in cases of initially performed serological studies of biological material from vaginal and anal/rectal swabs, where cotton swabs were spent.

\section{References}

1. Van Oorschot RA, Ballantyne KN, Mitchell RJ (2010) Forensic trace DNA: a review. Investig Genet 1: 14.

2. Budowle B, van Daal A (2009) Extracting evidence from forensic DNA analyses: future molecular biology directions. Biotechniques 46: 339-340, 342-50.
3. Mulligan CM, Kaufman SR, Quarino L (2011) The utility of polyester and cotton as swabbing substrates for the removal of cellular material from surfaces. J Forensic Sci 56: 485-490.

4. Gingras F, Paquet C, Bazinet M, Granger D, Marcoux- Legault K, et al. (2009) Biological and DNA evidence in 1000 sexual assault cases. Forensic Sci Int Genetics Supll Series 2 : 138- 140.

5. Sibille I, Duverneuil C, Lorin de la Grandmaison G, Guerrouache K, Teissière F, et al. (2002) Y-STR DNA amplification as biological evidence in sexually assaulted female victims with no cytological detection of spermatozoa. Forensic Sci Int 125: 212-216.

6. Horsman KM, Bienvenue JM, Blasier KR, Landers JP (2007) Forensic DNA analysis on microfluidic devices: a review. J Forensic Sci 52: 784-799.

7. Keating SM (1989) Information from penile swabs in sexual assault cases Forensic Sci Int 43: 63-81.

8. Hampton HL (1995) Care of the woman who has been raped. N Engl J Med 332: $234-237$.

9. Sweet D, Lorente M, Lorente JA, Valenzuela A, Villanueva E (1997) An improved method to recover saliva from human skin: the double swab technique. J Forensic Sci 42: 320-322.

10. GenePrint TM (1996) DNA Typing. Promega Corporation-Techical Manual.

11. Waye JS, Presley LA, Budowle B, Shutler GG, Fourney RM (1989) A simple and sensitive method for quantifying human genomic DNA in forensic specimen extracts. Biotechniques 7: 852-855.

12. Zaharova B, Andonova S, Decorte R, Leuven KU, Grozeva M (2003) DNA Paternity Testing in Bulgaria. Forensic Sci Int 136: 43-44.

13. Christov S, Apostolov A, Angelova $E$ (2003) DNA analysis of $Y$ chromosome markers in post-coital assays examination. Praemedicus XXII: 149-154.

14. Decorte R, Cassiman JJ (1996) Evaluation of the ALF DNA sequencer for highspeed sizing of short tandem repeat alleles. Electrophoresis 17: 1542-1549.

This article was originally published in a special issue, Forensic Medicine \& Current Research handled by Editor(s). Dr. Kaori Shintani-Ishida, University of Tokyo, Japan 